University of Wollongong

Research Online

Australian Institute for Innovative Materials -

Papers

Australian Institute for Innovative Materials

$1-1-2016$

In vitro PET/MRI diagnosis and targeted chemotherapy for cancer using radiolabeled nanoprobe : $A$ theragnostic approach

Bo-Bae Cho

Dongguk University

Mi Moon

Dongguk University

Justin Chellan

Dongguk University

Sang Y. Hwang

Dongguk University, samhwang@uow.edu.au

Jung Lee

Dongguk University

See next page for additional authors

Follow this and additional works at: https://ro.uow.edu.au/aiimpapers

Part of the Engineering Commons, and the Physical Sciences and Mathematics Commons

Research Online is the open access institutional repository for the University of Wollongong. For further information contact the UOW Library: research-pubs@uow.edu.au 


\title{
In vitro PET/MRI diagnosis and targeted chemotherapy for cancer using radiolabeled nanoprobe : A theragnostic approach
}

\author{
Abstract \\ The $68 \mathrm{Ga}$-labeled iron oxide (Fe 304 ) nanocomposites ( $68 \mathrm{Ga}(\mathrm{NF}) \mathrm{HFCNP}$ ) have been fabricated for \\ positron emission tomography (PET)/magnetic resonance imaging (MRI) diagnosis and targeted cancer \\ therapy. These radioisotopes labeled nanocomposites with folate conjugation have improved the \\ targeting property toward cancer cells. The chemotherapeutic drug doxorubicin (DOX) was loaded with 68 \\ Ga-labeled Fe 304 nanoparticles ( $68 \mathrm{Ga}(\mathrm{NF}) \mathrm{HFCNP}$ ) via intermediate DOX-Fe 2+ complex. The average \\ loading efficiency of DOX was $35 \%$ for NFHFCNP and $41 \%$ for HFCNP, respectively. In drug release profile, \\ the release rate of DOX from the nanocomposite was increased with respect to time. The cell lines, KB \\ and A549 treated with $68 \mathrm{Ga}(\mathrm{NF}) \mathrm{HFCNP}$ showed high cell viability and excellent cell uptake. Meanwhile, \\ the DOX-loaded nanocomposites exhibit high cytotoxicity toward these cell lines. These properties make \\ $68 \mathrm{Ga}(\mathrm{NF}) \mathrm{HFCNP}$ nanocomposite as a potential dual theragnostic probe for PET/MRI and targeted \\ chemotherapy for cancer cells.

\section{Disciplines} \\ Engineering | Physical Sciences and Mathematics

\section{Publication Details} \\ Cho, B., Moon, M. Mi., Chellan, J. Raj., Hwang, S. Hyuck., Lee, J. Hoon., Jung, S. Jae., Kim, B. Chul. \& Yu, K. \\ Hyun. (2016). In vitro PET/MRI diagnosis and targeted chemotherapy for cancer using radiolabeled \\ nanoprobe : A theragnostic approach. Bulletin of the Korean Chemical Society, 37 (6), 886-892.

\section{Authors} \\ Bo-Bae Cho, Mi Moon, Justin Chellan, Sang Y. Hwang, Jung Lee, Soon Jae Jung, Byung Chul Kim, and \\ Kook Hyun Yu
}




\title{
In Vitro PET/MRI Diagnosis and Targeted Chemotherapy for Cancer Using Radiolabeled Nanoprobe : A Theragnostic Approach
}

\author{
Bo-Bae Cho,${ }^{\dagger}$ Mi Mi Moon, ${ }^{\dagger}$ Justin Raj Chellan, ${ }^{\dagger}$ Sang Hyuck Hwang, ${ }^{\dagger}$ Jung Hoon Lee,${ }^{\dagger}$ \\ Soon Jae Jung, ${ }^{\dagger}$ Byung Chul Kim, ${ }^{\dagger}$ and Kook Hyun $\mathrm{Yu}^{\dagger, \ddagger}, *$ \\ ${ }^{\dagger}$ Department of Chemistry, Dongguk University-Seoul, Seoul 100-715, Republic of Korea. \\ *E-mail: yukook@dongguk.edu, \\ ${ }^{\ddagger}$ Korea Institute of Radiological and Medical Sciences, Seoul 139-706, Republic of Korea \\ Received February 5, 2016, Accepted March 24, 2016, Published online May 23, 2016
}

\begin{abstract}
The ${ }^{68} \mathrm{Ga}$-labeled iron oxide $\left(\mathrm{Fe}_{3} \mathrm{O}_{4}\right)$ nanocomposites $\left({ }^{68} \mathrm{Ga}(\mathrm{NF}) \mathrm{HFCNP}\right)$ have been fabricated for positron emission tomography (PET)/magnetic resonance imaging (MRI) diagnosis and targeted cancer therapy. These radioisotopes labeled nanocomposites with folate conjugation have improved the targeting property toward cancer cells. The chemotherapeutic drug doxorubicin (DOX) was loaded with ${ }^{68} \mathrm{Ga}-$ labeled $\mathrm{Fe}_{3} \mathrm{O}_{4}$ nanoparticles $\left({ }^{68} \mathrm{Ga}(\mathrm{NF}) \mathrm{HFCNP}\right)$ via intermediate DOX-Fe ${ }^{2+}$ complex. The average loading efficiency of DOX was $35 \%$ for NFHFCNP and $41 \%$ for HFCNP, respectively. In drug release profile, the release rate of DOX from the nanocomposite was increased with respect to time. The cell lines, KB and A549 treated with ${ }^{68} \mathrm{Ga}(\mathrm{NF}) \mathrm{HFCNP}$ showed high cell viability and excellent cell uptake. Meanwhile, the DOX-loaded nanocomposites exhibit high cytotoxicity toward these cell lines. These properties make ${ }^{68} \mathrm{Ga}(\mathrm{NF}) \mathrm{HFCNP}$ nanocomposite as a potential dual theragnostic probe for PET/MRI and targeted chemotherapy for cancer cells.
\end{abstract}

Keywords: Gallium-68, Doxorubicin, Chemotherapy, Positron emission tomography, Magnetic resonance imaging

\section{Introduction}

Cancer is a disease which can break orderly process of normal cells in the body and causes death. Despite the technical advancement of cancer diagnosis and therapy for last few decades, it has remained as a major public health concern. There are conventional treatments for cancer such as surgery, radiation, hormone, and chemotherapy. Among these, the most common therapeutic approach is chemotherapy which has been used either alone or in combination with other therapeutic techniques. ${ }^{1-3}$ Chemotherapy uses a highly efficient antineoplastic agent that kills cancer cells by preventing cell division or by drug toxicity which includes the anthracycline antibiotics; adriamycin and doxorubicin (DOX). DOX has been proven to be a very effective drug for the treatment of various cancers. ${ }^{4}$ Nevertheless, the severe side effects such as drug resistance and non-selective cytotoxicity curtail the utility of this drug. Therefore, it is necessary to develop site-specific delivery system to transfer drug and it can nullify the major obstacles of toxicity and drug resistance. ${ }^{2-4}$ Generally, nanoscale anticancer drug carriers have favorable properties like enhanced permeability and retention (EPR) effect. The highly stable nano-based carrier avoids the rapid renal excretion and prevents recognition by the reticuloendothelial system (RES), which enable effective accumulation in a solid tumor. As a result, those properties can decrease severe side effects of the drug by minimizing non-specific interactions. ${ }^{3,5,6}$ Recently, anticancer drug carriers based on magnetic nanoparticles (NPs) are effective and attractive approach for the biomedical applications. Superparamagnetic iron oxide $\left(\mathrm{Fe}_{3} \mathrm{O}_{4}\right)$ NPs are benefited as probe and delivery system for biological diagnosis and therapy because of their excellent chemical stability and biocompatibility. ${ }^{711}$ Specifically, radioisotope-labeled magnetic NPs are ideal probe for positron emission tomography (PET)/magnetic resonance imaging (MRI) which is a powerful tool to obtain necessary information in biomedicine. ${ }^{7,8,12}$ In the beginning, ${ }^{11} \mathrm{C}\left(t_{1 / 2}=20 \mathrm{~min}\right),{ }^{13} \mathrm{~N}\left(t_{1 / 2}=10 \mathrm{~min}\right)$, ${ }^{15} \mathrm{O}\left(t_{1 / 2}=2 \mathrm{~min}\right)$, and ${ }^{18} \mathrm{~F}\left(t_{1 / 2}=110 \mathrm{~min}\right)$ were the most used organic radionuclides for PET analysis. However, they have some limitations including high production cost for using cyclotron and relatively short half-lives. One of the alternative approach is to use metal radionuclide including ${ }^{68} \mathrm{Ga}\left(t_{1 / 2}=68 \mathrm{~min}, \beta^{+}=89 \%\right.$ and electron capture $(\mathrm{EC})=$ $11 \%$ ), which can be obtained easily from ${ }^{68} \mathrm{Ge} /{ }^{68} \mathrm{Ga}$ generator without the serve of cyclotron. ${ }^{8,13,14}$ Previously, we have reported the ${ }^{68} \mathrm{Ga}$-labeled water dispersible $\mathrm{Fe}_{3} \mathrm{O}_{4}$ NPs via $\rho$-SCN-Bn-1,4,7-triazacyclononane-1,4,7-triacetic acid (NOTA) as chelate agent for dual modality of PET and MRI diagnosis. Herein, we evaluated the ${ }^{68}$ Ga-labeled and folate-conjugated $\mathrm{Fe}_{3} \mathrm{O}_{4}$ NPs for in vitro PET/MRI diagnosis with enhanced targeted therapy. Folate can be applied as a targeting agent for chemotherapy because of their high 
binding affinity toward the cancer cells. Many studies have been reported on folate-conjugated nano-scale drug carriers using NPs, ${ }^{15,16}$, polymeric micelles, ${ }^{17,18}$ and liposomes ${ }^{19}$ for tumor targeting. Furthermore, the fabricated radioisotopelabeled nanocomposites were conjugated with anticancer drug DOX. The loading efficiency and release profile of the drug and its anticancer potential were studied in detail.

\section{Experimental}

2-(p-Isothiocyanatobenzyl)-1,4,7-triazacyclononane- $N$, $N^{\prime} N^{\prime \prime}$-triacetic acid trihydrochloride ( $p$-SCN-Bn-NOTA) was purchased from Futurechem (Seoul, Korea). The $\mathrm{GaCl}_{3}$ salt (mixture of two isotopes $\left[{ }^{69} \mathrm{Ga}-61.2 \%\right.$ and $\left.{ }^{71} \mathrm{Ga}-38.8 \%\right]$ ) and other chemical reagents were purchased from SigmaAldrich (St. Louis, MO, USA) and were used without further purification. Roswell Park Memorial Institute (RPMI) 1640 medium, Dulbecco's modified Eagle's medium (DMEM), fetal bovine serum, penicillin-streptomycin and phosphatebuffered saline (PBS, pH 7.4) were obtained from Gibco, Life Science, Life Technologies (Seoul, Korea). A murine colon cancer cell line CT-26 (folate receptor positive; FR+), human breast cancer cell line SK-BR-3 (folate receptor negative; FR-), HeLa contaminated cell line $\mathrm{KB}(\mathrm{FR}+)$ and lung cancer cell line A 549 (FR-) were purchased from Korea Cell Line Bank. (Seoul, Korea) ${ }^{20-22}$.

Preparation of HFCNP and NFHFCNP. ${ }^{68}$ Ga-labeled NPs were synthesized according to the scheme shown in Figure S1, Supporting Information. In the first step, the citrate was attached on the surface of iron oxide (FCNP) based on the protocol reported by Nigam et al. and Bumb et $a l$. . $^{8,10,23}$ The synthesized FCNP NPs (JCPDS Card No. 19-0629, $a=8.396 \AA$ ) have a negative surface charge because of the presence of carboxylate group and the average particle size was $\sim 9 \mathrm{~nm}$ (Figure S2). ${ }^{8}$ From the prepared FCNP $(4 \mathrm{mg} / \mathrm{mL})$ solution, $5 \mathrm{~mL}$ were stirred with $100 \mu \mathrm{L}$ of iodomethane at $40^{\circ} \mathrm{C}$ for $12 \mathrm{~h}$ and washed with methanol (12 $000 \mathrm{rpm}, 10 \mathrm{~min})$. Then, $100 \mu \mathrm{L}$ of hydrazine were added to the mixture and refluxed at $40^{\circ} \mathrm{C}$ for $5 \mathrm{~h}$ and stirred overnight at room temperature (RT). The obtained mixture (HFCNP) was washed with ethanol. NFHFCNP was prepared by reacting $10 \mathrm{~mL}$ of HFCNP $(0.2 \mathrm{mg} / \mathrm{mL})$ with $5 \mathrm{mg}$ of $(\rho-\mathrm{SCN}-\mathrm{Bn})-\mathrm{NOTA}$ and $8 \mathrm{mg}$ of folate at RT for $20 \mathrm{~h}$ in the presence of triethylamine, which acts as base. Finally, the resulting mixture (NFHFCNP) was washed and dispersed in ethanol solution. ${ }^{8}$ The structure of synthesized HFCNP and NFHFCP are shown in Figure 1. The NFHFCNP has folate and NOTA as a chelate agent on the surface and the HFCNP has hydrazide with citrate group on the surface. The functional groups on HFCNP have many oxygen and amine groups as hard Lewis base. In addition, HFCNP can have dual functions as chelate agent and diagnosis probe. Ga can be classified as a Lewis acid and form stable coordinated complexes with oxygen, nitrogen, and sulfur donor atom. $^{24,25}$ From the above-mentioned properties, it is clear that the Ga can easily bind to HFCNP without any chelating agent as well as NFHFCNP.

Radioisotope ${ }^{68}$ Ga Labeling with HFCNP and NFHFCNP. The non-radioactive reference compounds, GaHFCNP and GaNFHFCNP were prepared by reacting NPs with $\mathrm{GaCl}_{3}$ stock solution (1:10 molar equiv). The mixture of NPs $(0.1 \mathrm{mg} / \mathrm{mL}, 6 \mathrm{~mL})$ and $\mathrm{GaCl}_{3}$ stock solution $(500 \mu \mathrm{L})$ was stirred for $10 \mathrm{~min}$ at $100^{\circ} \mathrm{C}$ under refluxing condition. After $10 \mathrm{~min}$, the mixture was thoroughly washed and dispersed in deionized water (DW). The radiolabeling experiment of ${ }^{68} \mathrm{Ga}$ was conducted using ${ }^{68} \mathrm{GaCl}_{3}$ from ${ }^{68} \mathrm{Ge} /{ }^{68} \mathrm{Ga}$ generator (Eckert and Zeigler, Berlin, Germany) in $0.1 \mathrm{~N} \mathrm{HCl}$. Briefly, $1 \mathrm{M}$ sodium acetate buffer $(\mathrm{pH} 5.5)$ was added to ${ }^{68} \mathrm{GaCl}_{3}(1 \mathrm{mCi})$ followed by the addition of HFCNP and NFHFCNP $(200 \mu \mathrm{g} / \mathrm{mL})$ under stirring for $10 \mathrm{~min}$ at $40^{\circ} \mathrm{C} .^{8,13,14,26}$ Then, the free ${ }^{68} \mathrm{Ga}$ was eliminated by centrifugation ( $5 \mathrm{~min}, 3000 \mathrm{rpm}$ ) and the labeling efficiencies of ${ }^{68} \mathrm{GaHFCNP}$ and ${ }^{68} \mathrm{GaNFHFCNP}$ were measured using ITLC-SG eluted with $0.1 \mathrm{M}$ citric acid as a mobile phase. $^{8,26}$ The AR-2000 radio-TLC Imaging Scanner and CRC dosemeter were used to measure the radioactivity.

In Vitro Stability of ${ }^{68} \mathrm{Ga}$ Labeling of HFCNP and NFHFCNP in Human Serum. ${ }^{68}$ Ga-labeled HFCNP $(200 \mu \mathrm{L})$ and NFHFCNP $(200 \mu \mathrm{L})$ were incubated with $1 \mathrm{~mL}$ of human serum at $37^{\circ} \mathrm{C}$ under $5 \% \mathrm{CO}_{2}$ for 15,30 , 60,90 , and $120 \mathrm{~min}$ to evaluate the in vitro stability. After each time intervals, the stability was monitored through ITLC-SG using 0.1 M citric acid. ${ }^{19,20}$

Release Profile of Doxorubicin-loaded HFCNP and NFHFCNP. The drug loading efficiency and releasing profile of DOX-(NF)HFCNP was recorded using fluorescence spectrometer. DOX-loaded (NF)HFCNP was prepared according to the method proposed by Munnier et $a l^{27}$ The drug binding on NPs surface was investigated through a preformed DOX-Fe ${ }^{2+}$ complex, which is a mixture of DOX $(300 \mu \mathrm{g} / \mathrm{mL}$ in $\mathrm{pH} 7.4 \mathrm{PBS})$ and $\left(\mathrm{NH}_{4}\right)_{2} \mathrm{Fe}\left(\mathrm{SO}_{4}\right)_{2} \cdot 6 \mathrm{H}_{2} \mathrm{O}$ $\left(450 \mu \mathrm{g} / \mathrm{mL}\right.$ in DW). Then, the DOX-Fe ${ }^{2+}$ complex was incubated with (NF)HFCNP under dark for $15 \mathrm{~min}$. Various mass ratios of DOX 0.20/0.40/0.83/0.96 (w/w) with (NF) HFCNP $(120 \mu \mathrm{g} / \mathrm{mL})$ were prepared. After incubation, the DOX-(NF)HFCNP was centrifuged (15 $000 \mathrm{rpm}, 10 \mathrm{~min}$, $4^{\circ} \mathrm{C}$ ) to eliminate the non-conjugated $\mathrm{DOX}-\mathrm{Fe}^{2+}$ complex in supernatant. The DOX-loaded (NF)HFCNP was dispersed in sodium buffer solution $(\mathrm{pH} 4)$ for $20 \mathrm{~min}$ at $37^{\circ} \mathrm{C}$ in shaking incubator to measure the DOX loading efficiency. ${ }^{27}$ The sample was centrifuged and the released DOX concentration in supernatant was measured utilizing fluorescence spectrometry (Perkin Elmer LS 55B Luminescence Spectrometer, Perkin Elmer, Seoul, Korea). The in vitro release of DOX from (NF)HFCNP was studied in PBS (pH 7.4) at $37^{\circ} \mathrm{C}$. To measure the drug releasing rate, $200 \mu \mathrm{L}$ of DOX-loaded (NF)HFCNP [DOX/(NF)HFCNP$0.40(\mathrm{w} / \mathrm{w}), 120 \mu \mathrm{g} / \mathrm{mL}$ ] was added to $3.8 \mathrm{~mL}$ of PBS (pH 7.4) and incubated at $37^{\circ} \mathrm{C}$ under constant shaking. ${ }^{27}$ After subsequent time intervals, the tube was centrifuged (15000 rpm for $10 \mathrm{~min}, 4^{\circ} \mathrm{C}$ ) and the DOX released in 
(a)<smiles>CC1COC2CC(O)(C(=O)NN)CC(O1)O2</smiles><smiles>NNC(=O)C1(O)CC(=O)OC(O)C1</smiles>

(b)<smiles>COC1OCC2CC(O)(C(=O)NN)COC1CO2</smiles><smiles></smiles>

N-FHFCNP

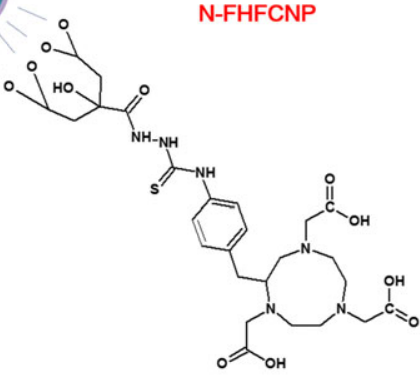

(c)

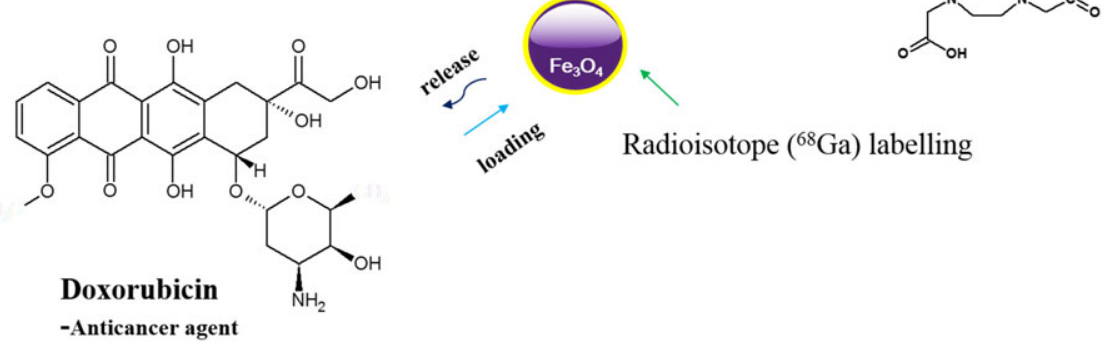

Figure 1. Structure of HFCNP without NOTA (a) and NFHFCNP with NOTA-folate (b). The image (c) illustrates the radioisotope (Ga68)-labeled nanocomposite-loaded anticancer drug (DOX) for diagnosis (PET/MRI-imaging) and chemotherapy toward cancer.

supernatant from (NF)HFCNP was determined by fluorescence spectrometry at $556 \mathrm{~nm}$ (excitation wavelength $490 \mathrm{~nm}$, emission range 530-700 nm). Each experiment was carried out in triplicate.

Cellular Uptake. Cell uptake studies were performed for $\mathrm{KB}$ and A 549 cell lines by the fluorescence microscopy (EVOS FL Auto, Life Technologies). Initially, the fluorescein isothiocyanate (FITC)-conjugated (NF)HFCNP was prepared by mixing (NF)HFCNP solution $(120 \mu \mathrm{g} / \mathrm{mL}$, $1 \mathrm{~mL})$ in ethanol and FITC solution $(1 \mathrm{mg} / \mathrm{mL}, 0.5 \mathrm{~mL})$ in acetone/water medium (0.3/2.7). As prepared solution was incubated for $20 \mathrm{~h}$ at $37^{\circ} \mathrm{C}$ in shaking incubator under dark condition. ${ }^{28}$ Then, the obtained mixture was thoroughly washed with PBS (pH 7.4) to eliminate the unreacted FITC and dispersed in $1 \mathrm{~mL}$ of cell culture medium (RPMI 1640). Cancer cells were placed in 8-well microscopy chamber with $1.0 \times 10^{4}$ cells per well and allowed to grow for $24 \mathrm{~h}$. After incubation, the cells were washed with PBS and fixed with $4 \%$ paraformaldehyde $(200 \mu \mathrm{L})$ for $15 \mathrm{~min}$, Then, the cells were again washed and incubated with FITC-conjugated (NF)HFCNP $(200 \mu \mathrm{L})$ for $30 \mathrm{~min}$. After the whole incubation process, the non-uptake (NF)HFCNP was washed with PBS and the nuclei of cell was stained with $200 \mu \mathrm{L}$ of $4^{\prime}, 6$-diamidino-2-phenylindole $(2 \mu \mathrm{g} / \mathrm{mL})$ in water for 10 min under dark. ${ }^{29}$ In addition, to compare ${ }^{68} \mathrm{GaNFHFCNP}$ (with folate) and ${ }^{68} \mathrm{GaNHFCNP}$ (without folate) uptake by CT-26 (FR+) and SK-BR-3 (FR-) cells, the cells were placed to grow in a 24-well plate $\left(1.0 \times 10^{5}\right.$ cells per/well $)$ for $24 \mathrm{~h}$ and incubated with ${ }^{68} \mathrm{GaNFHFCNP}$ and ${ }^{68} \mathrm{GaNHFCNP}(5 \mu \mathrm{Ci} /$ well $)$ at $40^{\circ} \mathrm{C}$ for 0.5 and $1 \mathrm{~h}$. Then, surface-bound radioactivity materials were removed using PBS and the cells were suspended in $0.1 \%$ sodium dodecyl sulfate in PBS. The radioactivity of cells and supernatant was measured by utilizing a gamma counter. ${ }^{8,13,14}$ Cytotoxicity Evaluation. EZ-CYTOX assay was performed to evaluate in vitro cytotoxicity of DOX-loaded (NF)HFCNP and Ga(NF)HFCNP on $\mathrm{KB}$ and A 549 cell lines. The $5 \times 10^{3}$ cells/wells were seeded into 96-well flat bottom plate for $24 \mathrm{~h}$. The $200 \mu \mathrm{L}$ of various concentration of DOX-loaded (NF)HFCNP and Ga(NF)HFCNP suspensions $(0,0.391,0.781,1.563,3.125,6.25,12.5,25,50$, $100 \mu \mathrm{g} / \mathrm{mL}$ ) were treated to the cells and incubated for 24, 48, and $72 \mathrm{~h}$. The untreated cells were used as a control. Each experiments were performed in triplicate. After incubation, EZ-CYOX reagent was added and again incubated for $4 \mathrm{~h}$ at $37^{\circ} \mathrm{C}$. The cell viability was calculated by recording absorbance at $450 \mathrm{~nm} .^{8,10}$

$$
\begin{aligned}
\% \text { Viability }= & (\text { absorbance of sample } / \text { absorbance of control }) \\
& \times 100
\end{aligned}
$$

\section{Results and Discussion}

Figure 2(a) shows the UV-visible absorption spectrum of nanocomposite with and without folate group. From the 
(a)

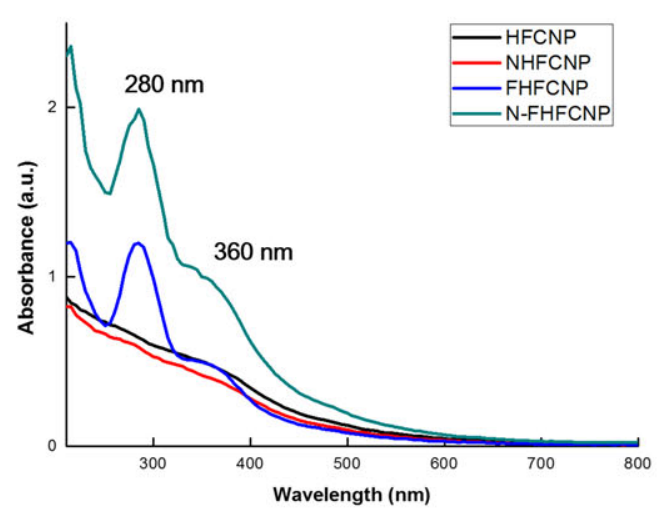

(b)

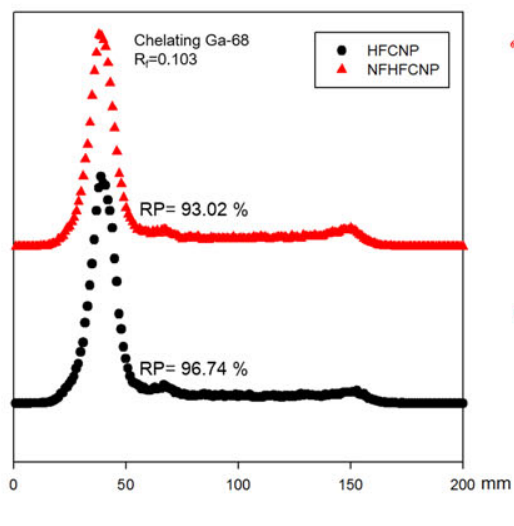

(c)
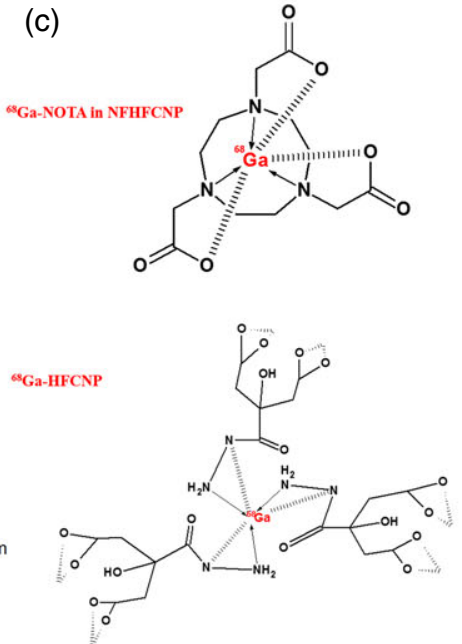

Figure 2. UV-visible absorption spectra for NPs with and without folate (a) and radio thin layer chromatogram (b); expected structure (c); of ${ }^{68} \mathrm{GaHFCNP}$ (RP: $96.74 \%$ ) and ${ }^{68} \mathrm{GaNFHFCNP}$ (RP: $93.02 \%$ ).

resultant figure, the samples FHFCNP and NFHFCNP show absorption peaks at 280 and $360 \mathrm{~nm}$ confirming the covalent attachment of the folate with NPs. ${ }^{15}$ But the corresponding folate absorption peaks were not observed in HFCNP and NHFCNP samples. Thus, the composite NFHFCNP with folate can easily be attached on tumor cell for targeted therapeutic. ${ }^{30}$

After chelating reaction for $10 \mathrm{~min}$, the compound with radioactivity of $277 \mu \mathrm{Ci}$ of ${ }^{68} \mathrm{GaNFHFCNP}$ and $280 \mu \mathrm{Ci}$ of ${ }^{68} \mathrm{GaHFCNP}$ were separated by centrifugation $(3000 \mathrm{rpm}$, $5 \mathrm{~min}$ ). The formation of ${ }^{68} \mathrm{GaHFCNP}$ and ${ }^{68} \mathrm{GaNFHFCNP}$ was shown in Figure 2(b). The chelating peaks of separated ${ }^{68} \mathrm{Ga}$ with NFHFCNP and HFCNP were assigned at $20.5 \mathrm{~mm}, R_{\mathrm{f}}=0.103$, where the Radiochemical Purity (RP) was $93.02 \%$ for NFHFCNP, $96.74 \%$ for HFCNP and the radioactivities were 254 and $264 \mu \mathrm{Ci}$, respectively. The corresponding peaks of free ${ }^{68} \mathrm{Ga}$ with low radioactivities of 20.2 and $20.4 \mu \mathrm{Ci}$ appeared at $116.4 \mathrm{~mm}, R_{\mathrm{f}}=0.582$ $(\mathrm{RP}=6.98 \%$ for NFHFCNP, $3.26 \%$ for HFCNP) on $0.1 \mathrm{M}$ citric acid. These results confirm that the chelating of ${ }^{68} \mathrm{Ga}$ in (NF)HFCNP can be easily obtained through short reaction time with a high yield. Figure 2(c) shows the expected structures of ${ }^{68} \mathrm{GaNFHFCNP}$ and ${ }^{68} \mathrm{GaHFCNP}$, which depicts that the ${ }^{68} \mathrm{Ga}$ atom was situated in the center of ${ }^{68} \mathrm{GaHFCNP}$ composites, which was further encapsulated by amine donors and conjugate with citrate group. ${ }^{24,25}$ The in vitro stability of ${ }^{68} \mathrm{GaNFHFCNP}$ and ${ }^{68} \mathrm{GaHFCNP}$ composites are shown in Figure S3. The resultant plot displays that the HFCNP can strongly bind with ${ }^{68} \mathrm{Ga}$ compared with NFHFCNP, because ${ }^{68} \mathrm{GaHFCNP}$ exhibited higher stability of $\sim 97.5 \%$ than ${ }^{68} \mathrm{GaNFHFCNP}$ of $\sim 87.5 \%$ at $120 \mathrm{~min}$. From these results, the encapsulation of $\mathrm{Ga}$ in HFCNP shows more strong binding effect than chelation effect of NOTA. ${ }^{24,25}$

Cell uptake of $\mathrm{Ga}(\mathrm{NF}) \mathrm{HFCNP}$ on $\mathrm{KB}$ and A 549 cell lines are shown in Figure S4. The fluorescence microscopic images show that the FITC-conjugated HFCNP and NFHFCNP shows high uptake on all cells within very short incubation time (30 $\mathrm{min}$ ) compared with long-time incubation $\left(3,12,24\right.$, and $48 \mathrm{~h}$ ) of previous reports. ${ }^{9,29,31}$ Moreover, the obtained cell uptake values of ${ }^{68} \mathrm{GaNFHFCNP}$ on CT-26 (FR+) and SK-BR-3 (FR-) for 0.5 and $1 \mathrm{~h}$ incubation time are shown in Figure 3.

In our previous research, we expected that the SK-BR-3 (FR-) cell membrane have more negatively charged sites than that of CT-26 (FR+) for high NPs adsorption. But the ${ }^{68}$ GaNHFCNP composite showed comparatively high uptake to SK-BR-3 (FR-) than that of CT-26 (FR+) cell line. ${ }^{8}$ To enhance the uptake of the NPs on CT-26 (FR+)
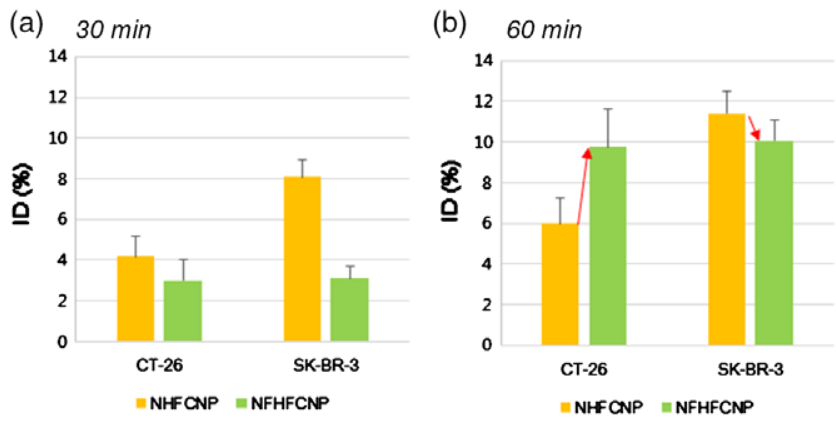

\begin{tabular}{|c|c|c|c|}
\hline Samples & Time & CT-26 & SK-BR-3 \\
\hline${ }^{68} \mathrm{Ga}$ & $30 \mathrm{~min}$ & $4.199 \pm 1.005$ & $8.08 \pm 1.049$ \\
\cline { 2 - 4 } NHFCNP & $60 \mathrm{~min}$ & $5.997 \pm 1.266$ & $11.402 \pm 1.092$ \\
\hline${ }^{68} \mathrm{Ga}$ & $30 \mathrm{~min}$ & $3.005 \pm 0.857$ & $3.124 \pm 0.588$ \\
\cline { 2 - 4 } & $60 \mathrm{~min}$ & $9.764 \pm 1.834$ & $10.059 \pm 1.014$ \\
\hline
\end{tabular}

Figure 3. Cell uptake of ${ }^{68} \mathrm{GaNFHFCNP}$ on $\mathrm{CT}-26(\mathrm{FR}+)$ and SK-BR-3 (FR-) cell lines at 30 (a) and 60 (b) min. 
cell line, an additional folate functional group was introduced into the ${ }^{68} \mathrm{GaNHFCNP}$. From Figure 3, it is clear that the cell uptake values of ${ }^{68} \mathrm{GaNHFCNP}$ and ${ }^{68} \mathrm{GaNFHFCNP}$ were increased with respect to incubation time. At 30 min incubation, cell uptake of ${ }^{68} \mathrm{GaNHFCNP}$ is higher than that of ${ }^{68} \mathrm{GaNFHFCNP}$. But at higher incubation time (60 min), the cell uptake of ${ }^{68} \mathrm{GaNFHFCNP}$ on CT-26 $(\mathrm{FR}+)$ was increased subsequently compared with ${ }^{68} \mathrm{GaNHFCNP}$ because of the presence of additional folate group. Thus, addition of folate group on the NPs can help effectively increase the cell uptake of CT-26 (FR+) compare to NPs without folate. And it showed a similar high uptake value of SK-BR-3 (FR-) cell line. These results of in vitro cell uptake of NPs promise for further use in vivo studies.

Drug loading efficiency and releasing profile of DOX from NPs were estimated using fluorescence spectroscopy. After the formation of intermediate $\mathrm{DOX}-\mathrm{Fe}^{2+}$ complex, the color of sample changes from bright red (DOX) to dark red $\left(\mathrm{DOX}-\mathrm{Fe}^{2+}\right)$ as represented in Figure S5. The loading efficiency of different concentration of DOX on (NF) HFCNP was calculated using the following relation and the resultant calibration curve of DOX solution is shown in Figure S5. ${ }^{27}$

$$
\text { Loading efficiency }(\%)=\mathrm{D} 2 / \mathrm{D} 1 \times 100
$$

concentration of DOX used before reaction (D1) and after reaction $(\mathrm{D} 2)$.

The DOX can bind to NPs by means of ionic interaction and iron chelation of $\mathrm{DOX}-\mathrm{Fe}^{2+}$. The $\mathrm{Fe}^{2+}$ ion has a role to form an intermediate between DOX and NPs. Both HFCNP and NFHFCNP have many oxygen and nitrogen groups, which can easily chelate with iron ion (Figure 1). ${ }^{27} \mathrm{At}$ $\mathrm{pH} 6$, the DOX is positively charged by protonated primary amine. ${ }^{10}$ The surface charge of synthesized HFCNP was observed to positive charge $(+8.84 \mathrm{mV})^{8}$ and that of NFHFCNP shows negative charge $(-14.85 \mathrm{mV})$. Thus, the DOX has more affinity to bound with negatively charged NFHFCNP than HFCNP. Figure 4(a) shows the loading efficiency with respect to various weight ratios of DOX in HFCNP and NFHFCNP nanocomposites. From the resultant plot, the loading efficiency of DOX on HFCNP is higher than that of NFHFCNP. Moreover, the compounds exhibit nearly similar value for various mass ratios of DOX/NPs (0.2/0.4/0.83/0.96). These observations show that the binding of DOX to HFCNP is mainly afforded by iron chelation. Moreover, both the compounds possess almost constant DOX loading efficiency from $31.32 \pm 0.19 \%$ to $38.28 \pm 0.18 \%$ for NFHFCNP and $40.74 \pm 0.02 \%$ to $43.87 \pm 0.01 \%$ for HFCNP. The resultant drug releasing profile of NPs are shown in Figure 4(b). The release rate of DOX from both the nanocomposite, HFCNP and NFHFCNP, depend up on time. The DOX release from NFHFCNP was increased sharply up to $8 \mathrm{~h}$ $(47 \pm 0.004 \%)$ and then, the releasing rate was gradually slowed and about $67 \pm 0.002 \%$ released after $48 \mathrm{~h}^{27}$ The release of DOX from NFHFCNP could be attributed to the weakening of the electrostatic interaction between DOX and NPs. ${ }^{10,27}$ In case of HFCNP, the DOX was very slowly released about $19.6 \pm 0.32 \%$ and $40.9 \pm 1.4 \%$ after 24 and 48 h by hydrolysis. ${ }^{27}$ The HFCNP and NFHFCNP showed a different releasing profiles of drug in spite of the same base NPs. This experiment evidence that the drug releasing profile can be adjusted by modifying the surface state of NPs.

Figure 5(a) shows the cell viability of $\mathrm{KB}$ and A549 incubated with $\mathrm{Ga}(\mathrm{NF}) \mathrm{HFCNP}$ for 48 and $72 \mathrm{~h}$. After the incubation period, $\mathrm{KB}$ and A549 cell lines exhibited higher (a)

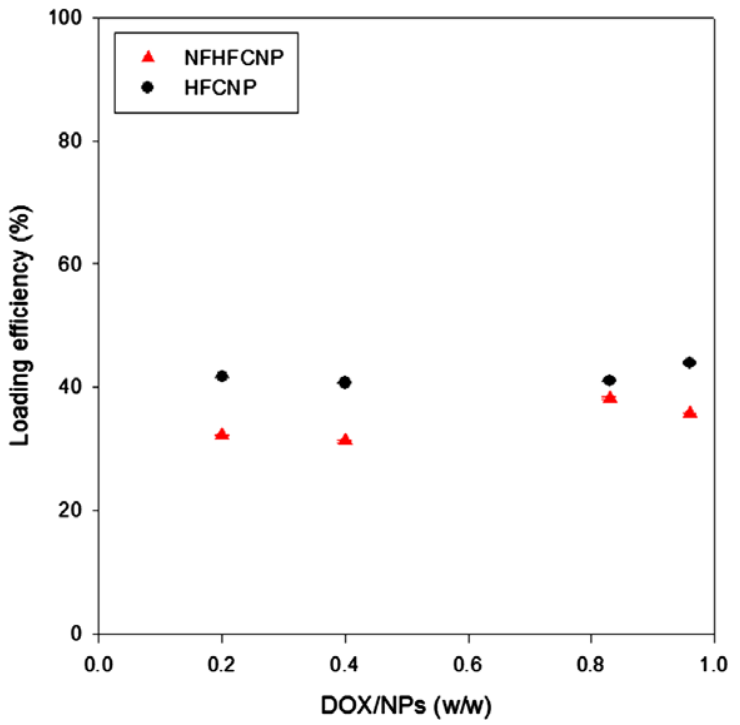

(b)

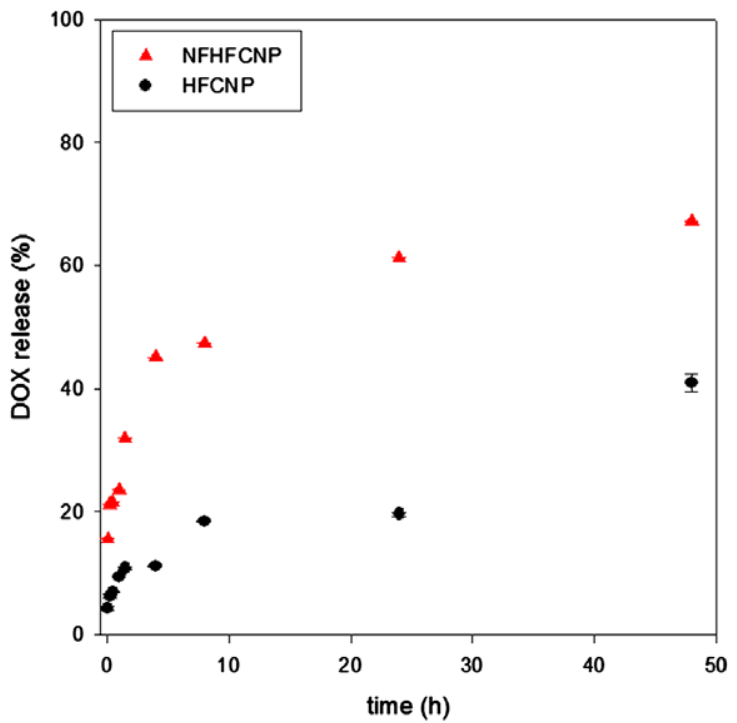

Figure 4. Loading efficiency of DOX on HFCNP and NFHFCNP (DOX/NPs weight ratio) (a); drug release profile of DOX-loaded NPs in vitro (PBS $\mathrm{pH} 7.4)(\mathrm{b})$ 
(a)

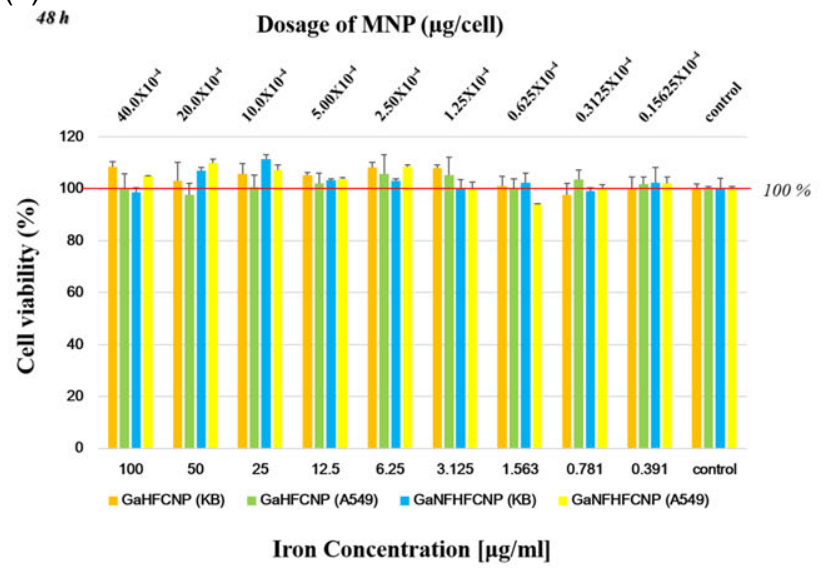

$72 \mathrm{~h}$

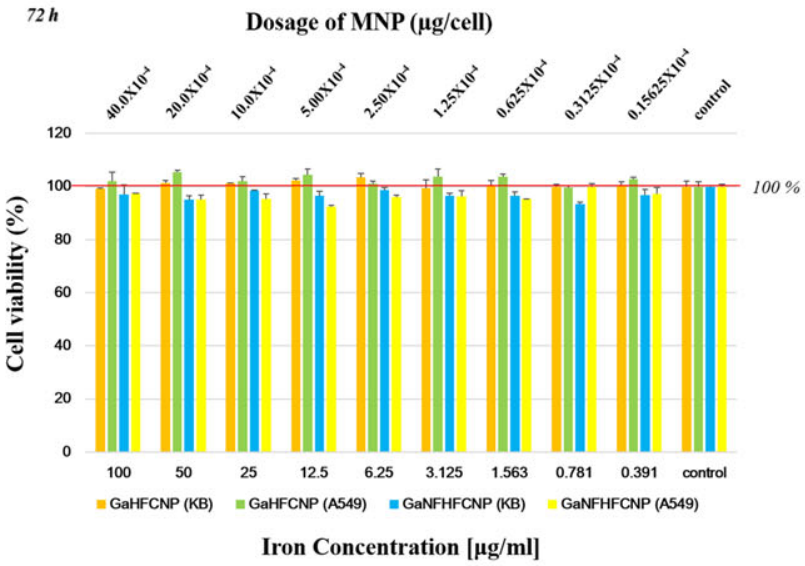

(b)
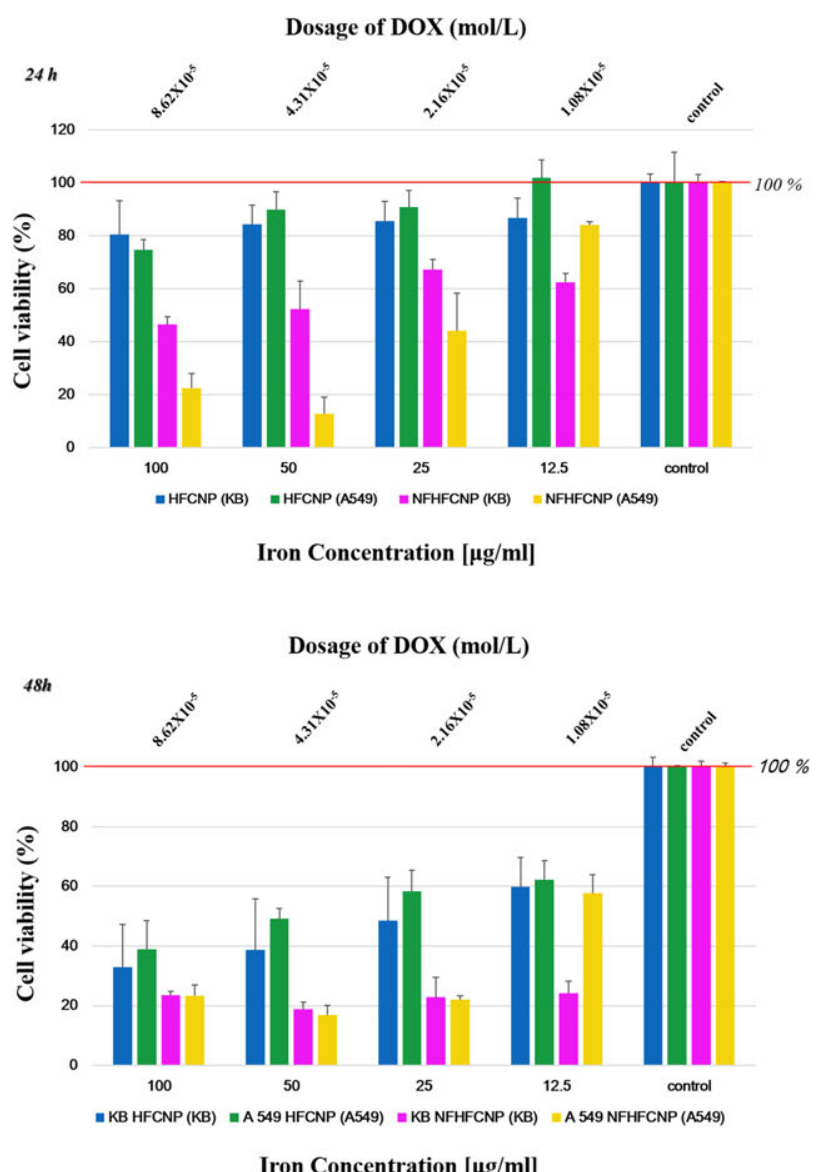

Figure 5. Cell viability of GaHFCNP and GaNFHFCNP on KB and A 549 cell lines for 48 and 72 h (a); cytotoxic activity of DOXloaded NPs on KB and A 549 cell lines for 24 and 48 h (b).

viability almost $100 \%$ toward $\mathrm{Ga}(\mathrm{NF}) \mathrm{HFCNP}$. The small variation of cell viability above $100 \%$ may be because of the properties of iron oxide, which can sometimes facilitate the cell growth. ${ }^{10}$ Moreover, the cells can continuously grow even at high concentration of $\mathrm{Ga}(\mathrm{NF}) \mathrm{HFCNP}$. This result represents the nontoxicity and excellent biocompatibility of Ga(NF)HFCNP. However, DOX-loaded NFHFCNP shows high cytotoxicity toward all tested cells, where each cell was affected by DOX-loaded NFHFCNP with different force. Even though the low concentration of DOX can also kills enough cancer cells. The cytotoxicity of DOX-loaded NFHFCNP for 24 and $48 \mathrm{~h}$ was shown in Figure 5(b). In case of HFCNP, KB and A 549 cell lines can survived $>80 \%$ even at strong concentration because of its slow drug releasing profile. Even after $48 \mathrm{~h}$ incubation, GaHFCNP shows cytotoxicity on the tested cells but the effects is comparatively less than that of GaNFHFCNP. These difference in cytotoxicity level is mainly because of the release rate of NFHFCNP and HFCNP, which was approximately 67 and 40\%, respectively. The exact statistical values of cell viability and cytotoxicity are shown in Tables S6 and S7.

\section{Conclusion}

In conclusion, we described the synthesis and evaluation of ${ }^{68} \mathrm{Ga}$-labeled and folate-conjugated $\mathrm{Fe}_{3} \mathrm{O}_{4}$ NPs with DOX as anticancer for dual modality, PET/MRI diagnosis and targeted cancer therapy. Folate was added to the NPs with EPR effect and which enhanced the targeting properties of the NPs. The covalent attachment of folate on NPs were confirmed through UV-vis absorption spectrum. The HFCNP and NFHFCNP shows excellent biocompatibility and high uptake on $\mathrm{KB}$ and $\mathrm{A} 549$ cell lines. Cell uptake of ${ }^{68} \mathrm{GaNFHFCNP}$ on CT-26 (FR+) increased with respect to time comparing with ${ }^{68} \mathrm{GaNHFCNP}$ composite. DOXloaded NPs through intermediate DOX-Fe ${ }^{2+}$ complex have a high cytotoxicity on the tested cells. The DOX loading efficiency shows nearly similar value for various mass ratio of DOX/NPs. The HFCNP showed higher loading efficiency than NFHFCNP and it released about $61 \pm 0.001 \%$ and $67 \pm 0.002 \%$ of loaded DOX after 24 and $48 \mathrm{~h}$, respectively. But HFCNP shows very slow drug releasing rate of $19.6 \pm 0.32 \%$ for $24 \mathrm{~h}$ and $40.9 \pm 1.4 \%$ for $48 \mathrm{~h}$. These detailed studies establish that ${ }^{68} \mathrm{GaHFCNP}$ and 
${ }^{68}$ GaNFHFCNP exhibit promising application for cancer contrast of PET/MRI and developing drug delivery for targeted chemotherapy.

Acknowledgment. This research was supported by National R\&D Program through the National Research Foundation of Korea (NRF) funded by the Ministry of Science, ICT \& Future Planning (No. 1711026888).

Supporting Information. Additional supporting information is available in the online version of this article.

\section{References}

1. K. Nam, H. Y. Nam, P. H. Kim, S. W. Kim, Biomaterials 2012, 33, 8122 .

2. C. Sanson, C. Schatz, J. F. Le Meins, A. Soum, J. Thevenot, E. Garanger, S. Lecommandoux, J. Control. Release 2010, 147, 428.

3. S. Lv, M. Li, Z. Tang, W. Song, H. Sun, H. Liu, X. Chen, Acta Biomater. 2013, 9, 9330.

4. N. V. Cuong, J. L. Jiang, Y. L. Li, J. R. Chen, S. C. Jwo, M. F. Hsieh, Cancers 2010, 3, 61 .

5. K. Miyata, R. J. Christie, K. Kataoka, React. Funct. Polym. 2011, 71, 227.

6. Y. H. Bae, K. Park, J. Control. Release 2011, 153, 198.

7. J.-H. L. Jin Woo Cheon, Acc. Chem. Res. 2008, 41, 1630.

8. B.-B. Cho, J. H. Park, S. J. Jung, J. Lee, J. H. Lee, M. G. Hur, C. Justin Raj, K.-H. Yu, J. Radioanal. Nucl. Chem. 2015, 305, 169.

9. D. H. Lee, M. Kang, H. J. Lee, J. A. Kim, Y.-K. Choi, H. Cho, J.-K. Park, T. H. Park, H. Jung, J. Nanosci. Nanotechnol. 2015, 15, 5512.

10. S. Nigam, K. C. Barick, D. Bahadur, J. Magn. Magn. Mater. 2011, 323, 237.

11. Y. Chang, X. Meng, Y. Zhao, K. Li, B. Zhao, M. Zhu, Y. Li, X. Chen, J. Wang, J. Colloid Interface Sci. 2011, 363, 403.

12. H. Hong, Y. Zhang, J. Sun, W. Cai, Nano Today 2009, 4, 399.

13. H. J. Kim, D. Y. Kim, J. H. Park, S. D. Yang, M. G. Hur, J. J. Min, K. H. Yu, Bioorg. Med. Chem. Lett. 2012, 22,5288 .
14. H. J. Kim, D. Y. Kim, J. H. Park, S. D. Yang, M. G. Hur, J. J. Min, K. H. Yu, Bioorg. Med. Chem. 2012, 20, 4915.

15. G. A. M. Ali Sharkeri-Zadeh, A. Reza Hashemian, H. Eshghi, A. Sazgarnia, A. Reza Montazerabadi, Dyn. Biochem. Process Biotechnol. Mol. Biol. 2010, 4, 6.

16. S. Mansouri, Y. Cuie, F. Winnik, Q. Shi, P. Lavigne, M. Benderdour, E. Beaumont, J. C. Fernandes, Biomaterials 2006, 27, 2060.

17. E. K. Park, S. Y. Kim, S. B. Lee, Y. M. Lee, J. Control. Release 2005, 109, 158

18. J. You, X. Li, F. de Cui, Y. Z. Du, H. Yuan, F. Q. Hu, Nanotechnology 2008, 19, 045102.

19. M. Kumar, G. Singh, V. Arora, S. Mewar, U. Sharma, N. R. Jagannathan, S. Sapra, A. K. Dinda, S. Kharbanda, H. Singh, Int. J. Nanomed. 2012, 7, 3503.

20. Y. W. Ying Wang, J. Xiang, K. Yao, Biomacromolecules 2010, 11, 3531.

21. J. Varshosaz, F. Hassanzadeh, H. Sadeghi-Aliabadi, F. Firozian, Biomed. Res. Int. 2014, 2014, 708593.

22. Y. Jang, S. Kim, W. K. Oh, C. Kim, I. Lee, J. Jang, Chem. Commun. 2014, 50, 15345.

23. A. Bumb, M. W. Brechbiel, P. L. Choyke, L. Fugger, A. Eggeman, D. Prabhakaran, J. Hutchinson, P. J. Dobson, Nanotechnology 2008, 19, 335601.

24. M. D. Bartholomä, Inorg. Chim. Acta 2012, 389, 36

25. I. Velikyan, Theranostics 2013, 4, 47.

26. Y. K. Lee, J. M. Jeong, L. Hoigebazar, B. Y. Yang, Y. S. Lee, B. C. Lee, H. Youn, D. S. Lee, J. K. Chung, M. C. Lee, J. Nucl. Med. 2012, 53, 1462.

27. E. Munnier, S. Cohen-Jonathan, C. Linassier, L. DouziechEyrolles, H. Marchais, M. Souce, K. Herve, P. Dubois, I. Chourpa, Int. J. Pharm. 2008, 363, 170.

28. N. Chekina, D. Horák, P. Jendelová, M. Trchová, M. J. Beneš, M. Hrubý, V. Herynek, K. Turnovcová, E. Syková, J. Mater. Chem. 2011, 21, 7630.

29. J. Zhu, L. Liao, L. Zhu, P. Zhang, K. Guo, J. Kong, C. Ji, B. Liu, Talanta 2013, 107, 408.

30. G. L. Zwicke, G. A. Mansoori, C. J. Jeffery, Nano Rev. 2012 3, 18496.

31. L. Zhang, S. Hou, S. Mao, D. Wei, X. Song, Y. Lu, Int J. Pharm. 2004, 287, 155. 